Proceedings

\title{
Laboratory Evaluation and Bioavailability of Termiticides in Tropical Soils to Subterranean Termites at Different Tempera- ture $^{+}$
}

Citation: Rashid, M.F.M.; Majid, A.H.A. Laboratory Evaluation and Bioavailability of Termiticides in Tropical Soils to Subterranean Termites at Different Temperature, in Proceedings of the 1st International Electronic Conference on Entomology, 1-15 July 2021, MDPI: Basel, Switzerland, doi:10.3390/IECE-10499 Published: 1 July 2021

Publisher's Note: MDPI stays neutral with regard to jurisdictional claims in published maps and institutional affiliations.

Copyright: (C) 2021 by the authors. Submitted for possible open access publication under the terms and conditions of the Creative Commons Attribution (CC BY) license (http://creativecommons.org/licenses/by/4.0/).

\author{
Mohd Fawwaz Mohd Rashid ${ }^{1}$ and Abdul Hafiz Ab Majid 1,* \\ 1 Household \& Structural Urban Entomology Laboratory,Vector Control Research Unit, \\ School of Biological Sciences, Universiti Sains Malaysia, \\ Penang, 11800 Minden, Malaysia \\ * Correspondence: abdhafiz@usm.my \\ + Presented at the 1st International Electronic Conference on Entomology (IECE 2021), 1-15 July 2021; \\ Available online: https://iece.sciforum.net/.
}

\begin{abstract}
Soil termiticide treatment is a fundamental method to control termite population and infestation. This method involves creating a continuous barrier surrounding the structures. However, termiticides may dissipate, depending on a half-life, degradation rate, leaching activity and storage method. In this study, the degradation rate and half-life of three commercially available termiticides, with active ingredient such as bifenthrin, fipronil and imidacloprid were determined under the field and laboratory conditions. The objective of this study was to determine the bioavailability of termiticides towards subterranean termites, Coptotermes gestroi under the laboratory conditions at two different temperature $30^{\circ} \mathrm{C}$ and $40^{\circ} \mathrm{C}$ using two types of soils i.e. sandy loam and loamy sand. Nochoice bioassay was done to determine the mortality rate for each termiticide tested. Types of termiticides showed a significant difference toward termite mortality $(\mathrm{F}=82.744 ; \mathrm{df}=2 ; \mathrm{P}=0.00)$. Bifenthrin revealed a higher termite mortality compared to fipronil and imidacloprid. Thus, the bifenthrin LT50 and LT95 values were lower compared to fipronil and imidacloprid. Termiticide concentration did affect the termite mortality $(\mathrm{F}=9.407 ; \mathrm{df}=2 ; \mathrm{P}=0.00)$ where the higher the concentration, the higher the termite mortality. The laboratory study on termiticide degradation indicated that bifenthrin was more persistent in the soils compared to fipronil and imidacloprid.
\end{abstract}

Keywords: termite baiting; chlorfluazuron; subterranean termite; termite ratio; mortality

\section{Introduction}

The global cost of termite infestations ranges from US\$ 22 billion to US\$ 40 billion [1]. The cost of damages from subterranean termites alone is estimated to be around $\$ 400$ million each year [1]. Chemical-based termiticides, primarily soil termiticides, account for about $90 \%$ of subsurface control products, with bifenthrin and imidacloprid accounting for $65 \%$. [2] . A properly applied soil-termiticide treatment should give good protection for at least 5 years [3] . Treatment efficiency of soil termiticides may differ depending on location [4], and termiticide susceptibility may differ depending on species [4]. [5]. Termiticide toxicity and mechanism of action are two critical aspects in determining the efficacy of termiticide-treated soil.

The goal of this study was to assess the bioavailability of termiticides against subterranean termites (Coptotermes gestroi) in the laboratory using two types of soils, sandy loam and loamy sand, at two different temperatures of $30^{\circ} \mathrm{C}$ and $40^{\circ} \mathrm{C}$. This was done using a no-choice bioassay to determine the mortality rate for each termiticide tested

\section{Materials \& Methods \\ Laboratory degradation study}




\section{Soil sampling}

For sandy loam, soil samples were taken from Durian Valley, Universiti Sains Malaysia (USM) $\left(5^{\circ} 21.35^{\prime} \mathrm{N} ; 100^{\circ} 18.16^{\prime} \mathrm{E}\right)$ and Teluk Bahang, Penang $\left(5^{\circ} 26.47^{\prime} \mathrm{N} ; 100^{\circ} 13.04^{\prime} \mathrm{E}\right)$. The soils were sampled from the top layer at a depth of about $10 \mathrm{~cm}$ (A-horizon). Stones, plants, and macro faunas were among the surviving detritus. At room temperature (20$25^{\circ} \mathrm{C}$ ), the soils were air-dried. The soils were then sieved using a $2 \mathrm{~mm}$ sieve, stored at room temperature, and air-dried. The particle size, $\mathrm{pH}$, and organic matter content of the soils were then determined. The $\mathrm{pH}$ of the soil was then measured using a $\mathrm{pH}$ metre (HANNA HI 8424, Romania). To obtain the $\mathrm{pH}$ value, the soils were combined with distilled water in a 1:2 ratio and left overnight (Chan, 2010).

\section{Termiticides}

There were three chemical families of termiticides used: chloronicotinyl (imidacloprid), phenyl pyrazole (fipronil), and pyrethroid (bifenthrin). Imidacloprid 200 SC (Ensystex, MALAYSIA Sdn. Bhd., Kuala Lumpur), Bifenthrin 100 SC (Ensystex, MALAYSIA Sdn. Bhd., Kuala Lumpur), and Fipronil 5.0 SC (Hextar Chemicals Sdn. Bhd., Selangor, Malaysia) were bought from a local supplier.

\section{Bioavailability of termiticides}

The data from the no-choice bioassay were analysed using log-probit analysis to determine the LT50 and LT95 with a 95\% confidence limit. To detect significant differences between the independent variables evaluated with termite mortality, a factorial analysis of variance (ANOVA) was done on termiticide, concentration, temperature, and soil types as independent variables (dependent variable). The Tukey's test at P0.01 was used to evaluate significant differences between the groups using a two-way ANOVA with termite mortality as the dependent variable. The control groups that had a mortality rate of more than $10 \%$ were retested, and all data was adjusted using Abbott's formula (Abbott, 1925).

$$
\mathrm{P}=(\mathrm{Po}-\mathrm{Pc}) /(100-\mathrm{Pc}) \times 100
$$

Where,

$\mathrm{P}=$ corrected mortality $(\%)$.

Po $=$ observed mortality $(\%)$.

$\mathrm{Pc}=$ control mortality $(\%)$.

\section{Result}

Bifenthrin, fipronil, and imidacloprid lethal time values (LT50 and LT95) were determined by counting dead termites in the first, third, sixth, twelfth, and twentieth months. The results showed that the LT50 and LT95 values rose over time, meaning that termiticide efficacy declined over time. Bifenthrin showed the lowest LT50 and LT95 values compared to fipronil and imidacloprid for all months tested. While, imidacloprid indicated the highest LT50 and LT95 values for all months tested compared to fipronil and bifenthrin.

There was a significant difference in termite mortality by month, according to statistical analysis $(\mathrm{F}=11.794 ; \mathrm{df}=3 ; \mathrm{P}=0.00)$. The LT50 and LT95 were lower in the first month compared to the 12th month (Table 1), indicating that it took the first month less time to kill $50 \%$ and $95 \%$ of the termites. There was a significant difference in termiticide types in 
terms of termite mortality $(\mathrm{F}=82.744 ; \mathrm{df}=2 ; \mathrm{P}=0.00)$. Termite mortality was higher with bifenthrin than with fipronil or imidacloprid. As a result, the LT50 and LT95 values of bifenthrin were lower than those of fipronil and imidacloprid. Termiticide concentration did affect the termite mortality $(\mathrm{F}=9.407 ; \mathrm{df}=2 ; \mathrm{P}=0.00)$ where the higher the concentration, the higher the termite mortality (Table 1 ).

Table 1: Effects of soil, month, termiticide, concentration and temperature on termite mortality for laboratory degradation study

\begin{tabular}{|c|c|c|c|c|}
\hline Source & $\mathrm{df}$ & Mean Square & $\mathbf{F}$ & Sig. \\
\hline Soil & 1 & 188.5 & $\begin{array}{l}0.399 \\
11.79\end{array}$ & 0.528 \\
\hline Month & 3 & 5578.502 & $\begin{array}{c}4 \\
82.74\end{array}$ & 0 \\
\hline Termiticide & 2 & 39137.72 & 4 & 0 \\
\hline Concentration & 2 & 4449.48 & 9.407 & 0 \\
\hline Temperature & 1 & 421.508 & 0.891 & 0.345 \\
\hline Soil * Month & 3 & 386.655 & 0.817 & 0.484 \\
\hline Soil ${ }^{*}$ Termiticide & 2 & 831.488 & 1.758 & 0.173 \\
\hline Soil * Concentration & 2 & 31.322 & 0.066 & 0.936 \\
\hline Soil * Temperature & 1 & 32.812 & 0.069 & 0.792 \\
\hline Month ${ }^{*}$ Termiticide & 6 & 553.94 & 1.171 & 0.319 \\
\hline Month * Concentration & 6 & 40.027 & 0.085 & 0.998 \\
\hline Month * Temperature & 3 & 584.451 & 1.236 & 0.295 \\
\hline $\begin{array}{l}\text { Termiticide }{ }^{*} \text { Concentra- } \\
\text { tion }\end{array}$ & 4 & 225.931 & 0.478 & 0.752 \\
\hline $\begin{array}{l}\text { Termiticide }{ }^{*} \text { Tempera- } \\
\text { ture }\end{array}$ & 2 & 524.961 & 1.11 & 0.33 \\
\hline $\begin{array}{l}\text { Concentration }{ }^{*} \mathrm{Tem}- \\
\text { perature }\end{array}$ & 2 & 13.822 & 0.029 & 0.971 \\
\hline $\begin{array}{l}\text { Soil * Month * Termiti- } \\
\text { cide }\end{array}$ & 6 & 135.174 & 0.286 & 0.944 \\
\hline $\begin{array}{l}\text { Soil * Month * Concen- } \\
\text { tration }\end{array}$ & 6 & 38.423 & 0.081 & 0.998 \\
\hline $\begin{array}{l}\text { Soil * Month * Tempera- } \\
\text { ture }\end{array}$ & 3 & 110.334 & 0.233 & 0.873 \\
\hline $\begin{array}{l}\text { Soil * Termiticide * Con- } \\
\text { centration }\end{array}$ & 4 & 22.792 & 0.048 & 0.996 \\
\hline $\begin{array}{l}\text { Soil }{ }^{*} \text { Termiticide }{ }^{*} \text { Tem- } \\
\text { perature } \\
\text { Soil }{ }^{*} \text { Concentration } *\end{array}$ & 2 & 76.36 & 0.161 & 0.851 \\
\hline $\begin{array}{l}\text { Temperature } \\
\text { Month * Termiticide* }\end{array}$ & $\begin{array}{l}2 \\
1\end{array}$ & 9.626 & 0.02 & 0.98 \\
\hline $\begin{array}{l}\text { Concentration } \\
\text { Month * Termiticide * }\end{array}$ & 2 & 48.925 & 0.103 & 1 \\
\hline $\begin{array}{l}\text { Temperature } \\
\text { Month * Concentration * }\end{array}$ & 6 & 281.345 & 0.595 & 0.735 \\
\hline Temperature & 6 & 22.087 & 0.047 & 1 \\
\hline $\begin{array}{l}\text { Termiticide }{ }^{*} \text { Concentra- } \\
\text { tion }{ }^{*} \text { Temperature }\end{array}$ & 4 & 4.982 & 0.011 & 1 \\
\hline $\begin{array}{l}\text { Soil }{ }^{*} \text { Month }{ }^{*} \text { Termiti- } \\
\text { cide }{ }^{*} \text { Concentration }\end{array}$ & $\begin{array}{l}1 \\
2\end{array}$ & 36.356 & 0.077 & 1 \\
\hline $\begin{array}{l}\text { Soil }{ }^{*} \text { Month }{ }^{*} \text { Termiti- } \\
\text { cide }{ }^{*} \text { Temperature } \\
\text { Soil }{ }^{*} \text { Month }{ }^{*} \text { Concen- }\end{array}$ & 6 & 149.548 & 0.316 & 0.929 \\
\hline $\begin{array}{l}\text { tration }{ }^{*} \text { Temperature } \\
\text { Soil }{ }^{*} \text { Termiticide }{ }^{*} \text { Con- } \\
\text { centration }{ }^{*} \text { Tempera- } \\
\text { ture }\end{array}$ & 6 & 14.42 & 0.03 & 0.998 \\
\hline
\end{tabular}




\begin{tabular}{|c|c|c|c|c|}
\hline \multicolumn{5}{|l|}{ Month * Termiticide * } \\
\hline Concentration * Tem- & 1 & & & \\
\hline perature & 2 & 7.803 & 0.016 & 1 \\
\hline \multicolumn{5}{|l|}{ Soil * Month * Termiti- } \\
\hline Temperature & 2 & 12.505 & 0.026 & 1 \\
\hline
\end{tabular}

df: degree of freedom; bold: significant value

\section{Discussion}

In comparison to fipronil and imidacloprid, bifenthrin produced the most termite mortality. Smith \& Rust [6] found that termite mortality in soil treated with bifenthrin was high despite being exposed to low concentrations. Imidacloprid, on the other hand, caused the lowest termite mortality. This result corroborated the ideas of Manzoor \& Pervez, [7], who suggested that bifenthrin provided the highest mortality among termiticides tested (bifenthrin and fipronil). The results were also supported by Saran \& Kamble [8], who revealed that LT50 and LT90 for bifenthrin were shorter, followed by fipronil and imidacloprid.

Temperature has a significant impact on termiticide degradation; the greater the temperature, the faster the process [9], [10]. There was no influence of temperature on termite mortality in this investigation. The exploratory activities of C. formosanus Shiraki were found to be substantially larger in sands with a temperature of $22^{\circ} \mathrm{C}$ compared to sands with a temperature of $28^{\circ} \mathrm{C}$ in a study by Gautam \& Henderson [11]. The bioavailability of imidacloprid in the laboratory was identical to the results in the field. A study by Ramakrishnan et al., [4] on termite mortality using imidacloprid at varying concentrations (25, 35 , and $50 \mathrm{ppm}$ ) on four types of soils found that imidacloprid administered in sandy loam and loam soils had no effect on termite mortality. In comparison to sandy clay loam, Manzoor \& Pervez [7] found that bifenthrin and fipronil were more effective in bioavailability experiments in sandy loam. Ramakrishnan et al., [4] found no significant difference in termite mortality in soils treated with imidacloprid in sandy loam and loamy sand, which corroborated the findings of this study. In contrast to this study, Manzoor \& Pervez [7] discovered a substantial variation in termite mortality across two types of soils (sandy loam and sandy clay loam). Finally, the bioavailability laboratory investigations revealed that among the termiticides examined, bifenthrin had the lowest LT50 and LT95 values. The breakdown and bioavailability of termiticides studied in the laboratory experiment were unaffected by soil type or temperature.

\section{Conclusion}

The bioavailability laboratory investigations revealed that among the termiticides examined, bifenthrin had the lowest LT50 and LT95 values. The breakdown and bioavailability of termiticides studied in the laboratory experiment were unaffected by soil type or temperature.

Author Contributions: Conceptualization: A.H.A.M.; methodology, A.H.A.M., and M.F.M.R; validation, A.H.A.M., and M.F.M.R.; formal analysis, M.F.M.R.; investigation, A.H.A.M., and M.F.M.R.; resources, A.H.A.M.; data curation, A.H.A.M., and M.F.M.R; writing - review and editing A.H.A.M., and M.F.M.R.; supervision, A.H.A.M.; and project administration, A.H.A.M.; funding acquisition. A.H.A.M. All authors have read and agreed to the published version of the manuscript.

Funding: This research was funded by Industrial Research Grant [304/PBIOLOGI/6501078/C132] and Research University Grant [1001/PBIOLOGI/8011104]. 
Acknowledgments. Our appreciation goes to Universiti Sains Malayisa Research [University Grant [Rui: 1001/PBIOLOGI/8011104] for the support and funding

Conflicts of Interest: Authors have no conflict of interest

\section{References}

[1] N.-Y. Rust, M. K., \& Su, "Managing social insects of urban importance.," Annu. Rev. Entomol., 2012, vol. 57, pp. 355-375.

[2] B. W. Koehler, P. G., Pereira, R. M., \& Jordan, “New techniques for subterranean termite control," in Proceedings of the Seventh International Conference on Urban Pests, 2011, pp. 1-4.

[3] P. G. Richman, D. L., Tucker, C. L., \& Koehler, "Influence of Portland cement amendment on soil pH and residual soil termiticide performance.," Pest Manag. Sci., vol. 1106, no. December 2006, 2006, pp. 1100-1106.

[4] G. W. Ramakrishnan, R., Suiter, D. R., Nakatsu, C. H., \& Bennett, "Feeding inhibition and mortality in Reticulitermes flavipes (Isoptera: Rhinotermitidae) after exposure to imidacloprid-treated soils.," J. Econ. Entomol., 2000, vol. 93, no. 2, pp. 422-428.

[5] P. Dhang, "A retrospective analysis of structures infested by subterranean termites in Philippines Partho Dhang.," in Proceedings of the Seventh International Conference on Urban Pests, 2011, pp. 3-8.

[6] M. K. Smith, J. L., \& Rust, “Tunneling response and mortality of the western subterranean termite (Isoptera: Rhinotermitidae) to soil treated with termiticides.," J. Econ. Entomol., 1990, vol. 83, no. 4, pp. 1395-1401.

[7] M. Manzoor, F., \& Pervez, "HPLC Analysis to determine the half-life and bioavailability of the termiticides bifenthrin and fipronil in soil.," J. Econ. Entomol., 2017, vol. 110, no. 6, pp. 2527-2533.

[8] S. T. Saran, R. K., \& Kamble, “Concentration-dependent degradation of three termiticides in soil under laboratory conditions and their bioavailability to eastern subterranean termites (Isoptera: Rhinotermitidae).," J. Econ. Entomol., 2008, vol. 101, no. 4, pp. 1373-1383.

[9] R. S. Ying, G.-G., \& Kookana, "Persistence and movement of fipronil termiticide with under-slab and trenching treatments.," Environ. Toxicol. Chem., 2006, vol. 25, no. 8, pp. 2045-2050.

[10] F. M. E. Zhu, G., Wu, H., Guo, J., \& Kimaro, “Microbial degradation of fipronil in clay loam soil.,” Water, Air, Soil Pollut., 2004, vol. 153, no. 1-4, pp. 35-44.

[11] G. Gautam, B. K., \& Henderson, "Comparative evaluation of three chitin synthesis inhibitor termite baits using multiple bioassay designs.," Sociobiology, 2014, vol. 61, no. 1, pp. 82-87. 